\title{
HILE Ü HUD'A: DECEPTION, DISSIMULATION AND MANIPULATION OF INFORMATION IN 16TH-CENTURY OTTOMAN EMPIRE
}

\author{
EMRAH SAFA GÜRKAN \\ Department of Political Science and International Relations \\ Elmalikent Cad. No: 434764 \\ Ümraniye Istanbul, Turkey \\ e-mail: emrahsafagurkan@gmail.com
}

This paper engages in methods of deception, dissimulation and manipulation that the Ottoman Empire employed in the 16th century. It demonstrates how the Ottomans misled their enemies in realms of diplomacy and warfare by feeding them with tailored information. They did not only successfully hide the target of their military preparations from enemy spies and foreign ambassadors, but also resorted to disinformation in order to manipulate diplomatic negotiations. Moreover, Ottoman commanders employed a number of tricks and ruses in order to gain the upper hand on the battlefield.

Key words: information-gathering, intelligence, Ottoman-Habsburg rivalry, disinformation, deception, dissimulation, espionage, decision-making.

\section{Introduction}

Due to the logistical and communicational difficulties of the time, early modern decision-makers were forced to operate with imprecise information, open to manipulation and often misleading. Accurate information was a precious commodity in short supply for which governments were always ready to spend fortunes. In fact, the 16th century witnessed the first experimentation with institutionalised secret services (Preto 1994; Sola 2005; Carnicer and Marcos 2005; Ribera 2007; Gürkan 2012; Varriale 2014; Iordanou 2019), only with mediocre results, however. Manipulated and fabricated information often carried the day, resulting in poor decisions with serious military and political consequences.

While 16th-century secret services were struggling with acquiring and transmitting accurate intelligence in a timely fashion, decision-makers in capitals and commanders on battlefields sought to get the upper hand in the war of information by trying 
to deceive their opponents with tailored information. This paper is about such efforts. Drawing from a wide range of primary sources from Ottoman and European archives, the following pages will try to study the methods and techniques of disinformation, deception, and dissimulation employed by one of the most powerful states of the 16th and 17 th centuries, the Ottoman Empire.

Although recently the Ottomanists started to scrutinise how early modern Ottomans acquired intelligence (Ágoston 2005, 2007), they did not focus on its mishandling and manipulation. The only exception is a recent paper dealing with the issue of rumor and misinformation by focusing on the confusion that prevailed on the battlefield in the Ottoman-Austrian frontier in 1663-1664 (Kolçak 2014). On the one hand, it analyses how commanders, soldiers and decision-makers were confused by false rumors regarding the outcome of decisive battles; on the other, it demonstrates how rivalling factions and disgruntled groups in both empires took advantage of this confusion for their own political ends. It does not concern, however, with a deliberate imperial strategy of disinformation aiming to control the outflow of intelligence and mislead the enemy - the main focus of this paper.

Moreover, daily negotiations between European diplomats and Ottoman decision-makers were rarely scrutinised, because archival documentation in Istanbul confines students of Ottoman diplomatic history to textual critique of ahdnames, commercial treaty-cum-peace agreements between Ottomans and Europeans (Theunissen 1998; Kołodziejczyk 2000, 2011; Yurdusev 2004); for a revisionist approach, see Gürkan 2015b, until very recently, see Işıksel 2016 and Talbot 2017. By expanding the source base with regular diplomatic correspondence and spy reports housed in Spanish and Venetian archives, we will scrutinise these negotiations and shed light on the intertwined nature of diplomacy, espionage and decision-making.

In three parts, we will try to demonstrate how 16th-century Ottomans developd a consistent strategy of information in order to reach their diplomatic and military objectices. The first part will show how they concealed their military target in order to refuse their enemies the opportunity to start the necessary preparations early. In the second part, we will concentrate on Istanbul's diplomatic milieu and analyse how Ottoman grandees employed disinformation to mislead foreign diplomats and reach their objectives in diplomatic negotiations. Finally, we will delineate the tricks and ruses on the battlefield that determined the victor.

\section{Quo Vadunt?}

One of the major duties of enemy intelligence services operating in the Ottoman lands was to learn the well-kept secret of where the Ottoman army or fleet was going to attack in the next campaigning season. The Ottomans usually kept this secret very well, not announcing the military target until the very last minute, sometimes even later. Venetian baili recorded that even grand admirals were left in the dark sometimes. They were handed a sealed letter containing the fleet's target which they could open days after they left Istanbul, only once they sailed past the Dardanelles (Albèri 1839- 
1863: Vol. I, 68-69, 425). Things were not different for land campaigns either. We do not know, for example, the destination of Mehmed II's last campaign which was cut short by his unexpected death in 1481; we can only deduce from the fact that it had camped in Hünkarçayırı on the Anatolian side of Istanbul that it was heading east. This could be deceptive though; even though the Ottomans could only do so much to prevent people from making educated guesses from military preparations and movements of the army and the fleet, they could still manipulate these predictions. In 1515, for instance, Selim I spread rumors that he would attack the Safavids rather than the Mamluks; he was trying to refuse the latter time to prepare for the eventual Ottoman attack and also to prevent the former from sending help to the Mamluks (Tansel 1969: 120-121). In order to feign an attack on Georgia, the Grand Vizier Sinan Pasha was sent to Anatolia where he would spread the word of the expedition and raise troops (TSMA Evrak 8277; facsimile in Tansel 1969: Appendix 27). This was a deliberate attempt to hide the real reason why the Ottoman Grand Vizier was personally supervising military preparations in Anatolia (Tansel 1969: 122). Selim furthermore showed his acumen in dissimulation when he assured Sultan Kansu Gavri that he meant no harm against the Mamluks. Even when the latter was in Aleppo and the Ottoman army was in Elbistan and when the war was only a few days ahead, Selim had no qualms about writing that the reason why his armies approached the Ottoman-Mamluk border was to enforce the ban on the Iranian trade via Aleppo and the port of Alexandretta; he would fight the Safavids with his army while his navy was in Syrian waters to defend the Ottoman realm against the infidels (Feridun H. 1274: 374; Tansel 1969: 132-133). Still after invading the Mamluk territory and killing Kansu at the Battle of Marj Dabik, Selim kept up his act. He would write to the new Sultan Tomanbay that his military preparations in Syria was not against him; it was Kansu Gavri's misdeeds that had prompted him to attack Egypt. His main target was Iran where he wanted to consolidate Sunni Islam; as long as Tomanbay accepted his suzerainty by coining the mint and having the hutba read in his name, he would not attack Egypt (Tansel 1969: 152-153). Needless to say, Selim was not a man to show mercy to the weak; in 1517, he would descend on Egypt, defeat end execute Tomanbay, and end the Mamluk State.

Learning Ottomans' naval intentions was even more important for enemy intelligence services because of the Ottoman navy's modus operandi. Ottoman naval threat was inherently unpredictable because of the speed with which the Ottomans could put together a fleet. Ottoman naval power depended on the number of ships and Ottoman galleys operated without experienced crews; this meant, as one expert summarised, 'while the western fleet required years of preparation and prudent husbandry [of experienced crews], the Ottoman fleet could emerge over one winter of intense activity organised from Constantinople' (Williams 2014: 154). Thus, it was of utmost importance for Ottomans' rivals to have a well-functioning intelligence network in Istanbul that could observe the military preparations in the Arsenal, bribe the scribes who penned orders as well as the couriers who carried them, and procure informants who could shed light on Ottoman intentions. The price for neglecting naval preparations and the movements of the Ottoman fleet could be heavy. The Habsburg defeat at Djerba (1560) clearly demonstrates how futile it was to acquire intelligence after 
the departure of the Ottoman fleet which in this case sailed at a remarkable speed and reached Djerba only in 20 days, catching the Duke of Medinaceli by surprise and destroying his fleet (Varriale 2014: 164). The defeat convinced the Habsburgs to institute a resident network composed of numerous agents, at one point reaching 112 persons and regularly paid from Madrid's coffers (AGS E 487, documents dated 16 April and 25 June 1569, E 1060, fol. 29 (9 May 1571); Sola 2005: 112). Even these wellpaid agents, however, had a hard time in ascertaining Ottomans' real target and their reports provided possibilities rather than certainties, indicating that the Ottomans could attack Cyprus or Crete or Malta or La Goleta and so on. The success of Ottoman dissimulation is once again evident in the Viceroy of Naples Cardinal Granvelle's insistence in 1574 that the Ottomans would not try to attack Tunis. As late as May, when there were clear signs that the Ottomans were going to undertake a major expedition, he assured Philip II that Tunis and La Goleta were safe because the Ottomans could not attack from the landward side and a fleet could not stay there for a long time (Coniglio 1987: Vol. II, 372). A month later, when, as he noted, the 'public rumor' (le bruict commun) had it that the Ottomans were targeting La Goleta and Tunis, he still insisted that South Italy and Sicily were more likely targets (Piot 1877-1896: Vol. 5, 152 [26 June 1574]). Needless to say, the Ottomans tried hard to conceal that La Goleta was in fact the prize in question. On 11 January 1574, it was proclaimed in the marketplace that Selim II would lead an expedition against Crete via Corfu or Zara, all Venetian strongholds (Gerlachium 1674: 44; Önal 2012: 318-319).

It was not only the Habsburgs that the Ottomans fooled. In 1499, the Venetians presumed that intensive preparations in the Arsenal were for an expedition targeting Rhodes that had been besieged nineteen years earlier; much to their dismay the Ottomans would declare war on them a couple of months later. ${ }^{1}$ Again on the eve of the 1551 expedition that would wreak havoc in Tyrrhenian and Ligurian waters, the Venetian bailo Bernardo Navagero seemed confident that Ottoman naval preparations were exaggerated: there was no way that the Ottomans could prepare 150 galleys until March and one of his expert informants (persona di pratiche) told him that preparations were not sufficient. According to the bailo, the Ottomans spread such false rumors in order to scare Charles V into returning al-Mahdiyya in North Africa to them; he boldly yet incautiously stated: 'I am so sure that I can risk my head that these rumors that a large fleet is almost ready will turn out to be vain, and I believe that the truce will be extended. ${ }^{2}$ Fortunately, in the end, he never made good on his bet!

Twenty years later, Marcantonio Barbaro was culpable of an even bigger failure of intelligence when he could not hear the drums of war in 1569-1570. Even though

${ }^{1}$ Sanudo 1879-1903: Vol. I, 880, 897, 906, Vol. II, 130, 147, 187-188, 233, 289-291, $380,386,421,505,507,536,554,567,573,597,599,609,610,612$. Nicolas Vatin pointed out that even though the Venetians started to have doubts towards the end of 1498, as late as May 1499 their ambassador to the Ottomans told in front of the Senate that naval preparations were most probably meant for Rhodes rather than somewhere in the Venetian stato da mar (Sanudo 1879-1903: Vol. II, 625 sq.; Vatin 1994: 241, fn. 4).

${ }^{2}$ Io son cosi certo come vivo e metterci la mia testa che questta voce di cosi grossa armata e cosi presta riuscira vana, anci credo io, che le tregue si prolongheranno (ASV, SAPC, fil. 5, cc. $29 \mathrm{r}-34 \mathrm{v}$ [1 January 1550 , more veneto $]$ ). 
he got wind of busy preparations in the Ottoman Arsenal, the first time he uttered the word Cyprus in his regular reports sent to Venice was 18 December (ASV, SDC, fil. 4, cc. 252r-252v), two months after the Ottomans had made up their minds (Charrière 1848-1860: Vol. III, 84, 87 (16 October 1569); BOA, MD IX, no. 204 (H. 10 Ca 977 / A.D. 21 October 1569), 231 (H. 10 Ca 977 / A.D. 21 October 1569). Ottoman officials managed to convince him that the fleet would set sail for other targets such as La Goleta and Cartagena, both belonging to the Habsburgs (ASV, SDC, fil. 4, cc. 245r-248r [10 October 1569]; also see BNM, Mss. It. VII, 390, Copialettere di Marcantonio Barbaro, 19 December 1569; Coco and Manzonetto 1985: 76; ASV, $S D C$, fil. 4, cc. 254r, 258r [20 December 1569]). Even after 18 December, Barbaro's confidants in the Ottoman government, such as the Grand Dragoman Ibrahim or the steward (kahya) of the deceased Grand Vizier Rustem Pasha and his wife, Mihrimah Sultan, ferociously denied rumors and suggested other targets (ASV, SDC, fil. 4, cc. 263r-265r [4 January 1569, more veneto]). Barbaro would know for sure that the Ottomans would attack Cyprus only when Sokollu Mehmed Pasha saw no problem in revealing the truth to him on 6 February (ASV, SDC, fil. 4, cc. 289r-294v [6 February 1569 , more veneto]), two months before the fleet left Istanbul.

Barbaro's intelligence failure had serious repercussions for Venice. Unable to learn Ottoman intentions on time, the Venetians started military preparations too late. Diplomatic negotiations for an alliance with Rome and Madrid cost further time. The allied fleet would not be able to sail to the Levant before September, allowing Ottoman commander Lala Mustafa to make the risky decision of disembarking 100 soldiers from each galley for a final assault on Nicosia (Barbero 2010: 263). The city would fall a day after the reinforcements arrived in Crete. The allied fleet could finally leave the islands nine days later, only to return halfway upon hearing the dire news and completing the entire campaigning season without so much as a cannon shot (Barbero 2010: 249). In short, successful disinformation sealed the fate of the most important Venetian colony in the Levant (a more detailed treatment in Gürkan 2018a).

The Ottomans did not hesitate to use disinformation while dealing with their allies. In order to convince the imperial envoy Gian Maria Malvezzi that they would not break the truce with the Emperor, the Grand Vizier Rustem Pasha told the French secretary Phébus that the Ottoman fleet would attack Malta. When Rustem Pasha's bet paid off and the secretary sent word to France, this crucial piece of information was immediately passed to Malta by the French dignitaries such as the Constable of France Anne de Montmorency and the Admiral of the French fleet in the Mediterranean Leon Strozzi who also sent his nephew Scipione to the island. Moreover, the Grand Admiral Sinan Pasha, Rustem's brother, maintained the fiction of a truce until the very last minute. When the Ottoman fleet was already in Calabrian waters, he asked the Viceroy of Sicily to peacefully return al-Mahdiyya, even though his real intention was to find a military rather than a diplomatic solution to the problem (Yerasimos 1992: 538-539).

While on the one hand, the Ottomans did their utmost to prevent their enemies from learning their targets, on the other hand, they spread rumors of attacks that would never realise. In August 1575, Habsburg spy Anibal Prothotico wrote from Corfu that 
the intelligence from Otranto of an incoming Ottoman attack proved to be false; such news was all Ottoman inventions to disturb the Habsburgs and push them on the defensive $^{3}$. In 1586, the Venetian bailo Lorenzo Bernardo guessed that the Ottoman fleet would not go far; it would sail until a certain point to arouse Habsburg suspicions. ${ }^{4}$ In 1592, Ruggiero Margliani, the Habsburg diplomat and spymaster in Ragusa, adroitly commented that the Ottomans could not dispatch a fleet this year; it was not only too late in the season but Habsburg spies in Istanbul had not mentioned major preparations in the Arsenal either. This could be a usual case of disinformation, he then added, similar to 'rumors that the Turks spread at other times and inventions with which Your Majesty's enemies try to put on alert' 1592]). Finally, it was not only Istanbul who used such rumors to put their enemies at unease. The Provveditor of the Venetian Fleet told the Habsburg spy Anibal Prothotico in 1575 that the Ottoman Governor of Delvine was spreading rumors of a large fleet in order to keep the Albanians, rebellious subjects of the Sultan, in check (AGS E 1066, fol. 61 [2 August 1575]).

\section{Diplomats in the Dark: Manipulating Diplomatic Negotiations}

Dissimulation and manipulation reigned in the realm of diplomacy as well. Diplomats were expected to be as much adroit negotiators as skillful information gatherers. ${ }^{6}$ Nevertheless, they often encountered difficulties in receiving accurate intelligence even from their own governments; they found themselves cut off from their capital especially in long-distance missions where they had to wait for a couple of months to receive instructions and news. Even though they did not struggle with finding spies and informants in cities with a cosmopolitan religious and ethnic fabric such as Istanbul, their intelligence capabilities mostly remained confined to capitals. They were rarely up-to-date with military and political developments in other parts of the empire such as the Persian front, for instance. Slowness of communication kept even the most talented spymaster in the dark and rendered diplomats fragile against Ottoman disinformation.

Aware of these difficulties, the Ottomans regularly fed foreign ambassadors with tailored information in order to lead them in their own direction. Truce negotiations between the Ottomans and the Habsburgs provide a series of cases in point. In order to pressure an otherwise recalcitrant Habsburg envoy Giovanni Margliani to

${ }^{3}$ Invention de turchi per dar disturbo a sua altessa accio non danifiche i loro luochi (AGS E 1066, fol. 66 [23 August 1575]).

${ }^{4}$ Per dar qualche suspetto a spagnoli (ASV, SDC, fil. 23, cc. 547r-548v [8 July 1586]).

${ }^{5}$ los ruidos hechizos que turcos han hecho otras vezes y las invenciones con que los enemigos de V.M. procuran ponernos en cuidado.

${ }^{6}$ Carnicer and Marcos (2005: 146) have gone as far as claiming that espionage was the real motive behind the establishment of resident embassies in foreign capitals. According to them, ambassadors' diplomatic functions merely provided a legal cover for their information-gathering activities. On Venetian baili's role in information gathering in Ottoman Istanbul, see Gürkan 2018b. 
finally sign the truce (for details of these negotiations, see Braudel 1966: 439-450; Skilliter 1971; Rodriguez-Salgado 2004; Gürkan 2012b: 291-312), the Ottomans spread rumors of major preparations in the Arsenal. In February 1580, negotiations stuck because Margliani was refusing to submit Philip II's letter and presents before the truce was officially signed. In order to coerce him, Uluc Ali went to the Arsenal and declared that the negotiations came to a halt. He then ordered the construction of 200 galleys and 10 galeasses $^{7}$ while his men were shouting 'Puglia, Puglia' in great joy. Habsburg informants in the Grand Admiral's household, however, informed Margliani that there were no preparations in the Arsenal and all was a mise-en-scène to strong-arm him (AGS, E 491, document dated after 17 February). A couple of months later, in July, this time the rumor had it that 300 galleys were being prepared in the Arsenal to attack either Sardinia or Puglia and that the Safavid Shah Mohammad Khudabanda was so desperate for peace that he was even ready to cede Şirvan, a town of key importance. Luckily for the Habsburgs, their seasoned spy Bartolomeo Pusterla warned them that these were all lies, burla; there were only preparations for 8 galeasses and the possibility of an Ottoman-Safavid Peace was nil. Needless to say, he turned out to be right; the war lasted for another ten years and there was no major Ottoman naval expedition throughout the 1580s (AGS, E 1337, fols. 163 [16 July 1580], 171 [3 September 1580], and 173 [18 September 1580]).

A three-year truce was finally signed in 1581 and renewed in 1584 . Negotiations for a third would break down in 1587, mostly due to the Ottomans' reluctance. Yet, both empires had few to gain from the resumption of hostilities, especially when their hands were tied in protracted wars in the Low Countries and Persia. So, diplomatic negotiations continued and with it usual efforts of manipulation. In May 1589, when the Habsburg envoy Giovanni Stefano Ferrari returned in Ragusa, the Grand Admiral Uluc Hasan Pasha went to the Grand Vizier Koca Sinan Pasha, breaking the news and advising him to order the preparation of 300 galleys in order to increase the empire's military reputation (per metter in maggior reputatione le forze di questo Signore) and thus negotiate with 'greater advantage' (il maggior vantaggio, ASV, SDC, fil. 29, c. 194v [12 May 1589]). In September, the bailo Giovanni Moro reported that in the last few days Sinan personally went to the Arsenal three times in order to supervise naval preparations. There were rumors (si discorre) that the Ottomans were planning an expedition next month because they received information that the Habsburg admiral Gianandrea Doria was in Syracuse with more than 70 galleys. Nevertheless, according to the same bailo, all these preparations were part of a ploy to convince Ferrari to come to Istanbul and start truce negotiations immediately (ASV, $S D C$, fil. 30, cc. 13r-14r [2 September 1589]).

Although much more welcome than the Habsburg ambassadors, the Venetian baili were no more immune to Ottoman machinations. When negotiations for peace reached a dead end, it was announced in January 1574 in the Grand Bazaar, Galata and other places in Istanbul that the Sultan would lead an expedition against either Corfu

${ }^{7}$ Galleasses are great galleys used for carrying merchandise and pilgrims. The Venetians transformed them by installing a platform on top of the forecastle and placed musketeers there. These proved extremely effective at the Battle of Lepanto, see Guilmartin 2003: 245-247. 
or Zara, only to follow up with Crete as the ultimate target (Gerlachium 1674: 44). Two years later, in peacetime, Don Cesar de la Mara, the resident Habsburg spymaster in Ragusa, reasoned that the Ottomans might be spreading rumors of military preparations in order to strong-arm the Venetians (AGS, E 1335, fol. 81 [8 February 1576]). Another two years later, when bailo Nicolò Barbarigo was trying to learn whether the rumors of a forthcoming expedition against Crete were accurate, he relied on one of his informants, a Venetian renegade. This renegade was a close friend of the Arsenal's proto (referring most probably to the Tersâne-i Âmire Emini) ${ }^{8}$ and the bailo had visited him both in his house and in the Imperial Arsenal. There, he gave Barbarigo a comprehensive tour more than once and the bailo could diligently observe the condition of the galleys and even count them one by one. It was the proto himself who showed them to the bailo; he even provided precise details: There were 181 galleys in total (including the old ones and the ones that were not yet put to the sea) in the Arsenal; nevertheless, only 50 of these were in sailing condition. They could prepare another 50 and if we add 30 new galleys under construction and 35 galleys that were on patrol duty, this number could go up to 170, still discounting the corsair galleys in North Africa that would join the fleet in case of a major expedition. There were also 15 or 16 fuste $^{9}$ and 7 galeasses with 6-7 others out on the sea (ASV, SDC, fil. 12, cc. 107r-108r [17 June 1578]). All this information was hinting at an expedition against Candia which would never take place. It was already impossible for the Ottomans to invest so much in a naval expedition when they had only recently entered into a costly war with the Safavids.

Why was the bailo allowed to visit the Arsenal and observe the military preparations freely? How come did the very official in charge of the Arsenal provide a foreign ambassador with detailed information on Ottoman military preparations, especially when those would target that ambassador's country? The answer to these questions is Uluc Ali's disinformation campaign. It was in the interest of the bellicose Grand Admiral, always lobbying for action in the Mediterranean (Gürkan 2015a), to appear 'aggressive' at this point (Castaño 2011: 271-272). The Grand Admiral also made sure that the bailo learnt of the conversation he had in his palace with his lieutenants and major Ottoman officials. The cunning corsair was broadcasting his antiVenetian sentiments: Sinan Pasha had made a mistake by not investing Corfu and now it would prove more difficult to take it because the Venetians had improved the fortifications. Given that Corfu was now inexpugnable, it was time to turn to Crete whose fortifications needed major improvements which could not be made easily. ${ }^{10}$

${ }^{8}$ According to the bailo, the equivalent of this office in the Venetian context was the admiralty of the Venetian Arsenal in charge of the construction of ships, warehouses, and workers (Munerotto 2009: 123-124). In the Ottoman Arsenal, it was the Tersâne-i Âmire Emini who undertook that function (Bostan 2003: 33-38).

${ }^{9}$ Fusta: a small galley with $10-15$ banks and a Latin sail. Often confused with galiots, fuste had two free oarsmen. For more details, see Gürkan 2018c: 136.

${ }^{10}$ Delli mancamenti che non si potevano tuor via cosi facilmente (ASV, SDC, fil. 12, c. 109r [17 June 1578]). 
Exaggerating or faking military preparations were not the only way of spreading fear in the enemy's heart. The Ottomans at times tried to deceive foreign diplomats with carefully staged mise-en-scènes. For example, in 1588, as soon as the bailo Giovanni Moro entered in Ibrahim Pasha's room, two gate-keepers (kapıcıbaşı) of Ferhad Pasha, the commander-in-chief in the east, entered as well. They showed Ibrahim the plans (dissegno) of the lands that the Ottomans had recently conquered. They then told the pasha that the Persians were ruined and the Shah was asking for peace, ready to bow to the Sultan's territorial demands and even offering his son as a hostage (ASV, SDC, fil. 28, c. 200r [27 November 1588]).

From the frequency of news regarding the Ottoman-Safavid War, one can conclude that the Venetians were always eager to learn what was going on in the Ottomans' eastern frontier; but then, the Ottomans were as eager to confuse them with false information. In another example, in 1616, while the Austrian ambassador and his retinue entered the second courtyard of the Topkap1 Palace for the first audience with the Sultan, two men on camels entered the courtyard, carrying big drums. Then followed the Ottoman soldiers, five Iranian captives enchained to each other and a hundred men each carrying on a rod three to five severed Iranian heads stuffed with hay (Werner 2011: 61-62). As they took their place on the left side of the Babü'ssaade (the Gate of Felicity), the entrance to the third courtyard, they must have left a lasting impression on the entire Austrian mission. The idea was not only to stage a show of force, but also to engage in disinformation by convincing the Austrian ambassador of Ottoman successes in the eastern front where in fact the Sultan's armies were failing miserably.

\section{Military Ruse: Hile ü Hud'a on the Battlefield}

Disinformation was of utmost importance for military operations where information reached its maximum value due to the contingency factor. On the battlefield, random events of otherwise minor importance could determine the winner and thus commanders did everything to trick each other into making mistakes. History books record a few far-sighted commanders such as the Roman Emperor Trajan who tried to train his troops on crafting impromptu responses to received intelligence by having his scouts bring in fabricated information (Austin and Rankov 1995: 50). Yet, he was an exception and most armies remained unprepared for the problem of contingency and the threat of mis- and disinformation.

One common ploy that the Ottomans employed was to create discontent among different ethnic groups in the enemy army by forging letters which included information that would turn them against each other. These letters were either carried to the enemy camp by Ottoman spies or located conveniently so that the enemy counterintelligence could intercept them. After the fall of Szigetvár in 1566, for instance, the Ottomans sought to capitalise on internal dissentions in the imperial army. The Chancellor (Nişancl) Feridun Ahmed, dragoman Ibrahim, and Mustafa Kethüda, the steward of Lala Mustafa Pasha, forged a number of letters in Croatian, German, Hungarian 
and Latin. Addressed to different regiments in the enemy camp, these would foster discord among them (aralarına muhkem adâvet ü nifâk $u$ şıkâka sebeb olub).

During the same expedition, the Grand Vizier Sokollu Mehmed Pasha displayed his competence in disinformation by using the moles in his army to create friction among the enemy soldiers (nifâk $u$ şıkâk düşürmek). Instead of executing these Hungarian and Austrian 'apostates' (mürted) who were regularly feeding their former coreligionist with intelligence from the Ottoman camp (mektûb gönderüb i'lâm u iş'âr), he offered them amnesty with the proviso that they would write letters to imperial soldiers. He then dictated a Hungarian mole to write to the Hungarian soldiers in the imperial army and warn them that the Ottomans were undertaking major preparations to continue the expedition. Moreover, Sokollu had him report that an Austrian noble arrived in the Ottoman camp in order to complain of Hungarian 'thieves' whose irresponsible depredations had started this war in the first place. The noble was there to ask for a separate peace. Sokollu then had an Austrian mole accuse the Hungarians in the same manner. According to Feridun Ahmed (2012: 66a-69a), this subtle trick (hile $\ddot{u}$ hud'a) forced the Emperor to break camp and retreat further north, to Györ. This was a great relief at the most unstable time for the Ottoman army: Sultan Suleiman I had just passed away and in order to prevent a disorder or mutiny, the Grand Vizier had to hide his death for more than a month until the new Sultan's arrival.

A similar ruse proved effective thirty-five years later when this time the Ottomans were on the defensive during the imperial siege of Nagykanizsa (1601). Instead of executing the caught enemy spies as ordered by the castle commander Tiryaki Hasan Pasha, beşli ă̆ası Ömer Ağa freed them, posing as a sympathetic Hungarian renegade: 'I am one of yours as well', he stated, 'I have come when I was little and become a servant to the pasha' (ben dahi sizdenim küçükden gelip paşa kulı olmuşum). Stating how happy he would have been had the castle fallen to the Christians, he then regretfully added that the chances of success were meager because the Ottomans still had one thousand men at arms with endless provisions (Naîmâ 2007: Vol. I, 188).

In another case from the same siege, when two Hungarian renegades defected (aslina ruch' eyledi) from the Ottoman camp and told the imperialists that the Ottomans were suffering from supply problems, Ömer A ğa resorted to a similar ploy. Under the usual guise of the sympathetic renegade, he freed a few enemy spies without forgetting to tell them that the two Hungarian defectors were in fact double agents, sent by Tiryaki for purposes of disinformation. According to Ömer's story, the duo were instructed to tell enemy commanders that the Ottoman garrison had few supplies left; their objective was to fool them into continuing the siege in the winter, only to fall prey to the Ottoman army that would come from Szigetvár. Simultaneously, the Ottomans left a letter near the imperial camp. Tiryaki supposedly wrote to the Ottoman commander-in-chief Yemişçi Hasan Paşa that he had secret dealings (ittifak) with Hungarian soldiers in the imperial army and that he sent two of his men to the enemy camp to spread false information. It is hard to know which one of these tricks, if not both, convinced the Austrians to kill the two Hungarians and put their severed heads on poles to show the besiegers that their stratagem failed (Naîmâ 2007: Vol. I, 194-195). One can only picture the smile on Tiryaki's face. 
Finally, in the middle of one night, enemy soldiers heard noises from the Ottoman castle: cannons were fired and the military band was playing in demonstration of joy. Then Tiryaki Hasan Pasha prepared a letter for the Ottoman commander-inchief who supposedly arrived in Szigetvár. The letter read that the enemy could not detect the reinforcements (350 janissaries, 100,000 gold coins, gunpowder, bullets and biscuits) that reached the castle last night. Tiryaki thanked the Commander-inChief Yemişçi for these reinforcements even though he had enough gunpowder and provisions for a year. He then asked him to give his steward Iskender 15,000 soldiers and once again mentioned his secret dealings with the Hungarians; he was planning a triple attack on the imperial army: himself from the castle, Iskender Pasha with 15,000 soldiers from Szigetvár and 30,000 Hungarian soldiers defecting from the imperial army. The letter was dropped near the enemy camp, only to be recovered by a cavalryman who gave it to the Emperor, claiming he took it from an Ottoman soldier by force, a lie most probably told in the hope of a bigger reward. Convinced of an enemy attack, the Emperor decided to put all the tents in one place and have ditches dug around their camp.

Tiryaki then employed a final ploy. He had two enemy soldiers caught and personally interrogated them. When soldiers talked about the letter and broke the news that the Austrians pillaged Hungarian soldiers' tents and put them to flight, the pasha feigned sorrow by putting his hands on his face and rubbing his eyes with a black towel immersed in onion juice (siyah dest-mâle soğan suyu olunmuş hazırlanmış idi). Then he ordered the execution of the two captives and the rest is usual story: Ömer Ağa freed them, accentuating his Christian sympathies and adding that the imperials should be careful on Sunday when the attack would take place and that the Hungarian soldiers were still around. The two soldiers returned to their camp and informed their commanders (Naîmâ 2007: Vol. I, 196-197).

As a result of these subtle tricks, the besieged Ottomans secured crucial tactical advantages on the battlefield: Hungarian soldiers left the imperial army, besiegers were fooled into believing that the Ottomans had enough provisions, enemy soldiers were demoralised and the imperial army was put on the defensive, reduced to digging ditches around the camp and waiting for an enemy attack. A couple of days later, the news of the Ottoman army's arrival in Szigetvár created chaos among soldiers who began to desert in great numbers. Realising the opportunity, Tiryaki undertook a surprise attack from the castle, forcing the enemy army to break siege and flee, leaving their cannons, weapons and gunpowder behind. His fine strategy of disinformation had saved the day.

While the Ottomans frequently used the spies that they caught for spreading false information, it was sometimes Ottoman spies who deceived their captors in order to save themselves. In 1514, while the Ottoman army was marching east to fight the Safavids, a spy called Şeyh Ahmed was sent to Iran by one of the pro-Ottoman Turcoman emirs and then caught by the enemy. Interrogated by Shah Ismail, the cunning spy told that he was sent by the Turcoman and other pro-Safavid elements from 
Rumelia and Anatolia ${ }^{11}$ who wanted to forge an alliance with the Shah, promising to change sides during the battle. It was not unusual for caught spies to pretend that they had some sort of a diplomatic mission in order to save their skin. When Habsburg saboteurs were detected in Istanbul in 1576, for example, their leader pretended to be an unofficial envoy sent from Madrid (Gürkan 2012b: 294-298). While this was an impromptu response, Şeyh Ahmed's ruse should be a premeditated one as he could produce letters written by Turcoman and Kurdish commanders. These sufficed to convince the Shah to give Ahmed several presents and send him back with letters for his new allies (Tansel 1969: 50-51).

A carefully propagated rumor by enemy spies could yield decisive results especially at critical junctures when uncontrollable events could determine the victor. At the Battle of Marj Dabik, for instance, Hayırbay and Canberdi Gazali, Mamluk grandees in cahoots with the Ottomans, spread the word that Sultan Kansu Gavri had died. They moreover urged Mamluk soldiers to flee for Aleppo to elect a new Sultan. Hearing this false rumor from their commanders, Mamluk soldiers started to flee towards the castle. Even though Gavri showed himself, trying to stop the disorder, his efforts were all in vain: he would be slain on the battlefield and the Ottoman army would emerge victorious (Tansel 1969: 139, fn. 206).

Deducing the enemy's strength, war readiness, weak spots and military plans from afar required a careful analysis of exterior evidence. Thus physical deception and dissimulation could lead the enemy to make major mistakes on the battlefield. Changing clothes, for instance, was a frequently used method. In 1506, the commander of the island of Lero saved his undermanned fortress from the Ottoman attack by having the island's inhabitants, men and women put on Maltese uniforms with white crosses. The Ottomans did not consider it worth to fight experienced soldiers which the Maltese knights undoubtedly were (Testa 2002: 11). A similar ruse worked against Ottoman admirals Uluc Ali and Kara Hoca in 1570. The small garrison of Curzola deceived otherwise cunning corsairs by dressing all the women in soldier's attire and having them move behind the walls with their pikes and helmets (Valente 1960: 122). It was not only castle garrisons that changed their appearance to fool their opponents. After the Battle of Lepanto in 1571, Istanbul sent orders to its commanders warning them that Christian galleys were sailing under the disguise of Muslim ships and that they should not allow them in their ports (BOA, MD XVI, nos. 139 [H. 4 C 979 / A.D. 23 October 1571] and 560 [H. 12 C 979 / A.D. 31 October 1571]).

If one cannot deceive, he can at least dissimulate; removing signs that would inform the enemy was especially important during the battle. Before the Battle of Lepanto, the commander of the Ottoman left wing Uluc Ali urged the Grand Admiral Müezzinzade to remove the flags and the lanterns so that the enemy could not recognise his galley (Kâtib Çelebi 2008: fol. 75b). This was what the commander of the Christian right wing Gianandrea Doria had in mind when he removed the great crystal globe which served as his lantern. Against accusations of cowardice, he just said

\footnotetext{
${ }^{11}$ Türkmân tâifesi ve Anadolu ve Rumili ümerâsı hizmetinde olan sufiler ve şeyh Erdebil hânedaninın muhibleri (Tansel 1969: 51).
} 
that it was a gift of his wife and he guarded it from sentiment. As he was not known for his emotional personality, few was convinced, needless to say. Everyone knew that the fact of the matter was he did not want his nemeses, the Ottoman corsairs, single him out during the battle (Rodgers 1986: 204).

Armies and navies were especially fragile during retreats. Commanders did everything to do it in an orderly and secret fashion. In 1557, while he was retreating from Fez after an indecisive battle with the Moroccan Sharif, the Governor General of Algeria Hasan Pasha made sure that the nearby Spanish forces did not get wind of his departure. He started retreating silently at midnight, leaving stakes that could light until sunset in his military camp. The Moroccan Sharif realised that the Ottoman army was gone only when he saw the empty mountains in the morning (Haedo 1612: 73; İlter 1936: Vol. I, 136).

The Ottomans themselves were wary of enemy deception. When deciding on a military strategy based on incoming intelligence, they rarely relied on one source and always compared information coming from different places. A good example is once again from the War of Cyprus. In June 1570, the Grand Admiral Müezzinzade and the Commander-in-Chief (Serdar) Piyale Pasha received orders to stay away from the enemy fleet. They in return sent news that the Allied fleet consisting of 90 galleys and 20 nefs (barça) was approaching Crete and offered to blockade them in case they entered a port. Istanbul, however, denied their request on the basis of the contradicting intelligence that it received from other sources. Kaya Bey had just returned from a reconnaissance mission with the letters of the zabit of the island of Andros, the Ragusan authorities, and the agent of the governor of Euboia; they all reported lower numbers which meant that the enemy fleet could not sail east. According to Istanbul, the Ottoman fleet should invest the enemy armada only if it were certain (muhakkak olsa) that it passed to Crete. The capital warned against the danger of operating with contradictory intelligence (bir sahîh haber olurda olmıyacak, bu ahbâr birbirine muvâfik değil) because the 'trickster infidel' (küffâr-ı hîlekâr) might be sailing in one direction to show the fleet and then returning to appear in another place, all in order to have the Ottomans overestimate their fleet's size. ${ }^{12}$ In the end, it turned out that Istanbul was right; the enemy fleet could only reach the port of Souda in Crete three months later, on 31 August.

Istanbul became even more risk-averse after the disastrous defeat at Lepanto. In 1572, Uluc Ali sent Istanbul a series of important intelligence: the Habsburg admiral Don Juan was going to set sail for Tunis with 40 galleys, leaving another 40 behind to join the Venetian fleet; the Venetians had 30 galleys in Messina; the relationship between Spain and France soured and the King of France would recall his 40 galleys. Istanbul was once again prudent: on 18 August, they warned the Grand Admiral Uluc Ali that the enemy fleet could be hiding somewhere while part of it was ap-

${ }^{12}$ Câiz ki bir cânibden yelken gösterüp, bu cânibe dahı firâr idüp, tekrâr görünmekle küllî gemi zann olınub (BOA, MD IX, nos. 237 and 239 [H. 23 Z 977 / A.D. 1 June 1570]). 
pearing here and there in order to lure him into sailing west into a trap. ${ }^{13}$ Moreover, the commander of the castle of Holomiç sent news that the enemy fleet anchored at the port of Zante. The Grand Admiral should not forget that these 'Frank infidels' (Frenk kâfirleri) were tricksters (ziyâde muhîl ve ehl-i hud'a mel'ûn); especially the Venetians, the Lord of the accursed (Venediklü deyyân-l melâ'in), always resorted to ruse and deception (mekr ü hîle, BOA, MD XIX, no. 668 [H. 9 Ra 980 / A.D. 18 August 1572]).

Even though Don Juan would have to wait until the following year to conquer Tunis, Uluc Ali's intelligence was at least partially accurate this time. The Hasburg Admiral had every intention to set sail for Tunis; but his brother Philip II had prohibited him from doing so. Then, he divided the Habsburg navy and ordered Don Juan on 4 July to leave behind 39 galleys for Gianandrea Doria who would patrol the Italian shores in search of North African corsairs until mid-August and, if nothing occurred by that time, then join the rest of the fleet. A large Christian fleet under the command of the Papal admiral Marcantonio Colonna sailed east without Don Juan's squadron. It left Messina on 7 July with 56 galleys; of these galleys, 13 belonged to the Pope, 18 to Spain and 25, not 30 as Uluc had claimed, to the Venetians (the French never had a single galley present). It reached Corfu on 20 July and Zante on 2 August; so the intelligence from Holomiç was correct. When the fleet reached Cerigo on 4 August, it had already united with the Venice's Adriatic fleet and grown in size: 145 galleys, 6 galeasses, 25 galiots $^{14}$ and 22 sails. It met the Ottoman fleet off the northeast shore of Cerigo between the islands of Servi (Elafonisi) and Dragonera on 7 August, 11 days before Istanbul sent the commandment that warned its Grand Admiral of possible enemy disinformation. The result was a draw as cunning Uluc Ali withdrew from the battle and sought refuge in Ottoman harbours. In the meantime, Don Juan would arrive in Corfu with his 50 galleys, 5 galliots and 2 galeasses on 9 August and wait there for the return of Colonna's fleet until 31 August. The fact that the two fleet could not join each other, as Uluc had guessed, paralysed the allied operation: Colonna and his Venetian colleague Foscarini refused to wait for Don Juan in Corfu and then warned him later not to sail east alone in order to join them; in the end when Uluc refused battle, they had to return to Zante to unite forces with Don Juan's squadron. All these unfruitful maneouvres cost them more than a month without receiving any strategic objectives in Ottoman waters (Setton 1976-1984: Vol. IV, 1081-1084).

${ }^{13}$ Kefere-i fecere hakîkatde bir yire külliyet ile cem 'iyyet idüb dahi suretâ ca-be-ca yalnuz gösterüb Donanma-yı Hümâyûn'a gaflet virmek içün her yire düşmek nâmuyla bir nişânlık sûretin göstermek ihtimâli vardur.

${ }^{14}$ Galiots were small oared vessels with $16-20$ banks instead of 25 as usual in ordinary galleys. Galiots used by the Ottoman corsairs should not be confused with Christian galiots. These may have had up to 24 banks and their difference from ordinary galleys was not the number of benches, but the lack of fore- or aftcastles. For more details, see Gürkan 2018c: 123-134. 


\section{Conclusion}

As was shown above, the Ottomans managed to deceive, dissimulate and manipulate effectively both in diplomatic and military spheres. They concealed their strategy, hid their military preparations and misled enemy decision-making by feeding them with tailored information. This active campaign of disinformation helped them solve the intelligence dilemma that Istanbul faced. In such a cultural, commercial, political and diplomatic centre, people of different geographical, ethnic, cultural and religious background intermingled with ease and beyond control. No other European city, not even Venice, could claim such a chaotic plurality. While this plurality made the Ottoman capital a centre of information par excellence towards which information flowed from four corners of the world (Ágoston 2005), it also created a constant leak of information. With surveillance and counter-intelligence techniques of the time (for Ottoman counter-intelligence, see Gürkan 2012a, 2017: Chapter Five), the Ottomans could not effectively monitor myriad forms of interactions between ambassadors, merchants, spies, pilgrims, sailors, soldiers of fortune, missionaries and vagrants of all stripes strolling through the ports, bazaars, and busy streets of their capital. What they could do, instead, was to control the news market by inundating it with contradictory information and making it increasingly difficult to sort through rumor and speculation.

On the battlefield, where misunderstanding was common to the extent that the defeated might consider himself the victor (Kolçak 2014: 172-173), the Ottomans succeeded in fooling their opponents as well. Competent and seasoned commanders appreciated the advantages that dissimulation and manipulation could provide. Ottoman sources' double standard towards the ethical side of deception proves that they were aware of its importance on the battlefield. While they accused Ottomans' rivals with a penchant for ruse of duplicitiousness, the same sources saw in Ottoman commanders employing similar stratagems astute military commanders proficient in their art. The most emblematic example of this attitude was the way Tiryaki Hasan Paşa was hailed in Ottoman sources. Deception was bad when used by their rivals; but as the end justified the means, it was only laudable when resorted to by the Ottomans.

\section{References}

AGS - Archivo General de Simancas

E- Papeles de Estado, busta 487, 491, 1060, 1066, 1093, 1335, 1337.

ASV - Archivio di Stato di Venezia

SAPC - Senato, Archivio Proprio Costantinopoli, filza 5.

SDC-Senato, Dispacci Costantinopoli, filza 4, 12, 23, 28, 29, 30.

BOA - Başbakanlık Osmanlı Arşivleri

MD - Mühimme Defterleri IX, XVI, XIX.

TSMA - Topkapı Sarayı Müzesi Arşivi

Evrak 8277.

BNM - Biblioteca Nazionale Marciana

Mss. It. VII, 390, Copialettere di Marcantonio Barbaro. 
AlbÈri, Eugenio (ed.) 1839-1863. Le Relazioni degli Ambasciatori Veneti al Senato durante il secolo decimosesto. 15 vols. Firenze: Società Editrice Fiorentina.

Austin, Norman J. E. and N. Boris RANKOV 1995. Exploratio: Military and Political Intelligence in the Roman World from the Second Punic War to the Battle of Adrianople. London and New York: Routledge.

ÁGoston, Gábor 2007. 'Information, Ideology, and Limits of Imperial Policy: Ottoman Grand Strategy in the Context of Ottoman-Habsburg Rivalry.' In: Virginia H. AKSAN and Daniel GOFFMAN (eds.) The Early Modern Ottomans: Remapping the Empire. Cambridge: Cambridge University Press, $75-103$.

BARBero, Alessandro 2010. Lepanto: La battaglia dei tre imperi. Roma and Bari: Laterza.

Bostan, İdris 2003. Osmanlı Bahriye Teşkilatı: XVII. Yüzyılda Tersane-i Amire. Ankara: Türk Tarih Kurumu.

BRAUDEL, Fernand 1966. La Méditerranée et le monde méditerranéen à l'époque de Philippe II. 2 vols. [2nd ed.] Paris: Armand Collin.

CARNICER, Carlos and Javier MARCos 2005. Espías de Felipe II: Los servicios secretos del Imperio español. Madrid: La esfera de los libros.

CASTAÑo, Emilio Sola 2011. Uchalí: El Calabrés Tiñoso, o el mito del corsario muladí en la frontera. Barcelona: Edicions Bellaterra.

ChARrière, Ernest (ed.) 1848-1860. Négociations de la France dans le Levant, ou, Correspondances, mémoires et actes diplomatiques des ambassadeurs de France à Constantinople et des ambassadeurs, envoyés ou résidents à divers titres à Venise, Raguse, Rome, Malte et Jérusalem, en Turquie, Perse, Géorgie, Crimée, Syrie, Egypte, etc., et dans les états de Tunis, d'Alger et de Maroc. 4 vols. Paris: Impr. Nationale.

Coco, Carlo and Flora Manzonetto 1985. Baili veneziani alla Sublime Porta. Venezia: Stamperia di Venezia.

Coniglio, Giuseppe (ed.) 1987. Il viceregno di Napoli e la lotta tra spagnoli e turchi nel Mediterraneo. 2 vols. Napoli: Università degli Studi.

FERIDUN Ahmed Beg 2012. Nüzhet-i Esrâr-ü'l-Ahyâr der Ahbâr-ı Sefer-i Sigetvar. [Ed. H. Ahmet ARSLANTÜRK and Günhan BÖREKÇı.] İstanbul: Zeytinburnu Belediyesi Kültür Yayınları.

FERIDUN Beg 1274 (Hijri). Mecmû'a-yı Münşe'âtü's-Selatîn. İstanbul: Matbaa-yı Amire.

Gerlachium, Samuelem (ed.) 1674. Stephan Gerlachs deß Aeltern Tage-Buch, der von zween glorwürdigsten Römischen Käysern, Maximiliano und Rudolpho beyderseits den Andern dieses Nahmens, höchstseeligster Gedächtnüß, an die Ottomannische Pforte zu Constantinopel abgefertigten... Franckfurt am Mayn: Zunner.

GuILMARTIN, John Francis Jr. 2003. Gunpowder and Galleys: Changing Technology and Mediterranean Warfare at Sea in the Sixteenth Century. [Rev. ed.] London: Conway Maritime Press.

GÜRKAN, Emrah Safa 2012a. 'The Efficacy of Ottoman Counter-Intelligence in the 16th Century.' AOH 65/1: 1-38.

GÜRKAN, Emrah Safa 2012b. Espionage in the 16th Century Mediterranean: Secret Diplomacy, Mediterranean Go-Betweens and the Ottoman-Habsburg Rivalry. (Ph.D. Dissertation, Georgetown University.)

GÜRKAN, Emrah Safa 2015a. 'Fooling the Sultan: Information, Decision-Making and the "Mediterranean Faction" (1585-1587).' Journal of Ottoman Studies 45: 57-96.

GÜRKAN, Emrah Safa 2015b. 'Mediating Boundaries: Mediterranean Go-Betweens and Cross-Confessional Diplomacy in Constantinople, 1560-1600.' Journal of Early Modern History 19: $107-128$.

GüRKAN, Emrah Safa 2017. Sultanın Casusları: 16. Yüzyılda Istihbarat, Sabotaj ve Rüssvet Ağları. İstanbul: Kronik Kitap. 
GÜRKAN, Emrah Safa 2018a. 'Desinformación y rumores en Estambul en el comienzo de la Guerra de Chipre (1569-1570).’ In: Gennaro VARRIALE (ed.) ¿Si fuera cierto? Espias y agentes en la frontera (siglos XVI-XVII). Alcalá de Henares: Universidad de Alcalá, 48-61.

GÜRKAN, Emrah Safa 2018b. 'Laying Hands on Arcana Imperii: Venetian Baili as Spymasters in Sixteenth-Century Istanbul.’ In: Paul MAdDrell et al. (eds.) Spy Chiefs, Volume 2: Intelligence Leaders in Europe, the Middle East, and Asia. Washington, D.C.: Georgetown University Press, 67-96.

GÜRKAN, Emrah Safa 2018c. Sultanın Korsanlart: Osmanlı Akdenizi'nde Gazâ, Yağma ve Esaret, 1500-1700. İstanbul: Kronik Kitap.

HAEdo, Diego de 1612. Topographia e Historia General de Argel, repartida en cinco tratados, do se veran casos estraños, muertes espantosas, y tormentos exquisitos, que conuiene se entiendan en la Christiandad: con much doctrina, y elegancia curiosa. Valladolid: Diego Fernandez de Cordoua y Ouiedo.

IORDANOU, Ioanna 2019. Venice's Secret Service: Organising Intelligence in the Renaissance. Oxford: Oxford University Press.

IŞIKSEL, Güneş 2016. La diplomatie ottomane sous le règne de Selîm II: paramètres et périmètres de l'Empire ottoman dans le troisime quart du XVI siècle. Paris: Peeters.

İLTER, Aziz Samih 1936. Şimali Afrika'da Türkler. 2 vols. İstanbul: Vakit Matbaası.

KÂTIB ÇELEBI 2008. Tuhfetü'l-Kibâr fi Esfâri'l-Bihâr. [Ed. İdris Bostan.] Ankara: T.C. Başbakanlık Denizcilik Müsteşarlığı.

KOLÇAK, Özgür 2014. ““Cümle Palankaları Küffâr Aldı...”: 1663-64 Osmanl1-Habsburg Savaşında Dezenformasyon, Propaganda ve Siyasî İktidar.' The Journal of Ottoman Studies 43: $165-$ 192.

KoŁodZIEJCZYK, Dariusz 2000. Ottoman-Polish Diplomatic Relations (15th-18th Century): An Annotated Edition of "Ahdnames and Other Documents. Leiden: Brill.

KoŁodzIEJCZyK, Dariusz 2011. The Crimean Khanate and Poland-Lithuania: International Diplomacy on the European Periphery (15th-18th Century). A Study of Peace Treaties Followed by Annotated Documents. Leiden: Brill.

Munerotto, Gianfranco 2009. Dizionario illustrato Storico-Tecnico dei principali termini di costruzione navale e marineria veneziana. Venezia: Mare di Carta.

NAÎMÂ Mustafa Efendi 2007. Tarih-i Naîmâ. 4 vols. [Ed. Mehmet İPşıLLI.] Ankara: Türk Tarih Kurumu Yayınları.

ÖNAL, Ahmet 2012. Koca Sinan Paşa'nın Hayatı ve Siyasî Faaliyetleri (1520-1596). (Ph.D. Dissertation, Marmara Üniversitesi.)

Piot, M. Charles (ed.) 1877-1896. Correspondance du Cardinal de Granvelle, 1565-1583. 12 vols. Bruxelles: Académie Royale.

Preto, Paolo 1994. I Servizi Segreti di Venezia. Milano: Il Saggiatore.

RIBERA, Jean-Michel 2007. Diplomatie et espionnage: Les ambassadeurs du roi de France auprès de Philippe II du traité du Cateau-Cambresis (1559) à la mort de Henri III (1589). Paris: Honoré Champion Editeur.

Rodgers, William Ledyard 1986. Naval Warfare under Oars, 4th to 6th Centuries: A Study of Strategy, Tactics and Ship Design. Annapolis: Naval Insitute Press.

Rodríguez-Salgado, M. J. 2004. Felipe II, el "Paladín de la Cristiandad y la paz con el Turco". Valladolid: Universidad de Valladolid.

SANUDO, Marino 1879-1903. I diarii di Marino Sanuto (MCCCCXCVI-MDXXXIII) dall'autografo Marciano ital. cl. VII codd. CDXIX-CDLXXVII. 58 vols. Venezia: F. Visentini.

SetTon, Kenneth M. 1976-1984. The Papacy and the Levant (1204-1571). 4 vols. Philadelphia: American Historical Society. 
SKILliter, S. A. 1971. 'The Hispano-Ottoman Armistice of 1581.' In: Clifford E. BosworTH (ed.) Iran and Islam: In Memory of the Late Vladimir Minorsky. Edinburgh: Edinburgh University Press, $491-515$.

SolA, Emilio 2005. Los que van y vienen: Información y fronteras en el Mediterráneo clasico del siglo XVI. Alcalá de Henares: Universidad de Alcalá.

SolA, Emilio 2011. Uchalí: El Calabrés Tiñoso, o el mito del corsario muladí en la frontera. Barcelona: Edicions Bellaterra.

TALBot, Michael 2017. British-Ottoman Relations, 1661-1807: Commerce and Diplomatic Practice in Eighteenth-Century Istanbul. Woodbridge: The Boydell Press.

TANSEL, Selahattin 1969. Yavuz Sultan Selim. Ankara: Milli Eğitim Basımevi.

Testa, Carmel 2002. Romegas. Malta: Midsea Books.

Theunissen, Hans 1998. 'Ottoman-Venetian Diplomatics: the 'Ahd-names. The Historical Background and the Development of a Category of Political-Commercial Instruments together with an Annotated Edition of a Corpus of Relevant Documents.' Electronic Journal of Oriental Studies 1/2: 1-698.

Valente, Gustavo 1960. Vita di Occhiali. Milano: Casa Editrice Ceschina.

VARRIALE, Gennaro 2014. Arrivano li Turchi: guerra navale e spionaggio nel Mediterraneo (15321582). Novi Ligure: Città del silenzio.

VATIN, Nicolas 1994. L'Ordre de Saint-Jean-de-Jérusalem, l'Empire ottoman et la Méditerranée orientale entre les deux sièges de Rhodes, 1480-1522. Paris: Peeters.

Werner, Adam 2011. Padişahın Huzurunda: Elçilik Günlügü̈, 1616-1618. [Trans. Türkis NoYAN.] İstanbul: Kitap Yayınevi.

WiLliams, Phillip 2014. Empire and Holy War in the Mediterranean. New York: I. B. Tauris.

YERASIMOS, Stéphane 1992. 'Les relations franco-ottomanes et la prise de Tripoli en 1551.' In: Gilles VeInstein (ed.) Soliman Le Magnifique et son Temps: Actes du Colloque de Paris Galeries Nationales du Grand Palais, 7-10 Mars 1990. Paris: La Documentation Française, 529547.

Yurdusev, A. Nuri (ed.) 2004. Ottoman Diplomacy: Conventional or Unconventional? New York: Palgrave MacMillan. 